\title{
An Empirical Study on the Effects of Real Effective Exchange Rate on Algeria's Trade Balance
}

\author{
Yasmina Guechari \\ School of Finance, Shanghai University of Finance and Economics \\ Zhong Shan North No.1 Road, No. 369, Shanghai 200083, China \\ E-mail: lilia2105@hotmail.fr
}

Received: September 30, 2012

Accepted: October 11, 2012

Online Published: October 13, 2012

doi:10.5430/ijfr.v3n4p102

URL: http://dx.doi.org/10.5430/ijfr.v3n4p102

\begin{abstract}
The purpose of this study is to estimate the effects of Real Effective Exchange Rate (REER) on Algeria's trade balance (TB). There exist two groups of studies that have investigated in the short-run and long run effects of real effective exchange rate on trade balance. The first group has employed at aggregate level between Algeria and the rest of world. The second group has used the trade at the bilateral level between Algeria and her two major trading partners, US (as a largest export partner of Algeria) and France (as a largest import partner of Algeria). Since a country's trade balance behavior is directly depending on real effective exchange rate (REER), foreign income ( $\mathrm{Y}^{*}$ ) and real domestic income (Y), so, we include all these variables in our model to test the general case (Algeria-world case) and specific case (Algeria-France and Algeria-UScase). This study uses unit root tests, co-integration techniques, Error Correction Model (ECM) and impulse response function with time series data covering the periods of 1981Q1-2009Q4. The main findings of this study are: (i) REER have a significant expected impact (positive in long-run and negative in short-run) on the Algeria bilateral trade balance with respect to US and France, and on the total trade balance. (ii) The Granger Causality test suggests that REER does Granger causes trade balance for all cases of study. The study clearly demonstrates that real devaluations of exchange rate in Algeria have been positively associated with improvement of trade balance. Hence, devaluation of currency as a whole seems to be beneficial for Algeria exports.
\end{abstract}

Keywords: Trade balance, Real effective exchange rate, Co-integration, Error Correction Model (ECM), Granger causality

\section{Introduction}

This study focuses on three major determinants of trade balance, namely the exchange rate, domestic and foreign incomes. Theoretically, the real effective exchange rate should be an important determinant of exports and imports of a country since it represents the rate at which the domestic goods and services that can be exchanged with the output produced by the foreign countries. The real effective exchange rate is one of the essential economic indicators of economy's international competitiveness, and therefore, has a strong influence on country's foreign trade developments. In particular, the impact of the real effective exchange rate developments on foreign trade has been a topic of discussions in both developed and developing economies. Numerous empirical investigations of how exchange rate changes affect the trade balance (or the export-to-import ratio) in the long run and short run have been done for industrialized economies; given that Algeria is a commodity exporting country, so there is still ambiguous whether devaluation of domestic currency really improves its trade balance; so to solve this problem and other issues about trade balance relationships with its determinants I try to analyze the effects of real effective exchange rate on trade. It should be noted that there are no published studies on the effect of real exchange rate on trade balance and the existence of the J-curve phenomenon for Algeria economy. Hence, this study aims at contributing in this area.

\section{Literature Review}

Numerous studies have been to measure the effects of exchange rate changes on trade balance. The results have been mixed; some studies have found that exchange rate is an important determinant of trade balance while others found otherwise; Specifically, Arize (1994) showed that there is a long-run relationship between the trade balance and the real effective exchange rate using data for nine Asian economies. On the other hand, Ogbonna (1982) analyzes the 
1973 devaluation of the Naira (Nigerian currency) in Nigeria's balance of payments and he concludes that devaluation fails to improve the balance of payments. Bahmani-Oskooee (2001) investigated the long-run response of Middle Eastern countries' trade balance to devaluation by applying the Engle-Granger and Johansen-Juselius cointegration methodology. The evidence suggests that there exist a favorable long-run effect of a real depreciation on the trade balance for all seven countries (Algeria, Bahrain, Egypt, Jordan, Morocco, Tunisia, and Turkey). Gomes \& Paz (2005) and Tsen (2006) find the existence of a long run relationship between trade balance, real exchange rate, foreign and domestic income for Brazil and for Malaysia respectively during 1965-2002. Rose and Yellen (1989) could not reject the hypothesis that the real exchange rate was statistically insignificant determinant of trade flows. They examined the bilateral trade flows between the United States and other OECD countries using quarterly data

More recently, numerous papers have tested the ML condition and J-curve, some of them supported the hypothesis that the real devaluation improve trade balance in other words (the ML condition exist) see for example: Bahmani-Oskooee and Tatchawan Kantipong (2001) found in case of Thailand versus its five major trading partners (Germany, Singapore, Japan, UK and US) the evidence of the J-curve in bilateral trade with US and Japan only. They used quarterly data from 1973 to 1997 and ARDL cointegration. Kanta Marwah and Lawrence R. Klein (1996) also investigated influence of the real bilateral exchange rate on bilateral trade balance in both the US and Canada with their respective five largest trading partners. Quarterly data cover the period between 1977 and 1992. They maintained that after depreciation, trade balance, both in the US and Canada, follows an S-curve pattern, i.e. after the initial J-curve shape trade balance has a tendency to worsen again by the end. Rose (1991) reported the Marshall-Lerner condition does not exist in five major OECD countries (United Kingdom, Canada, Germany, Japan, and the United States). Her results also showed insignificant relationship between trade balance and exchange rate, thus implying that devaluation could not improve trade balance in the long run.

\section{Overview of Algeria's Trade and Exchange Rate}

\subsection{Algeria Foreign Trade and Its Major Trading Partners}

Algeria's small-to medium-sized economy is largely dependent on the hydrocarbons sector, which accounts for about 95 percent of export earnings. Algeria is a member of UN, African Union and OPEC (Organization of Petroleum-Exporting Countries). In 2009, total exports of the country totaled to US \$52.03 billion. Major items of export are hydrocarbons and animal products, with the US as its largest exporting partner. However, the country imports largely from France. Major items of import are consumer goods and food materials, agricultural and industrial equipments. Algeria's export trade has almost doubled in the period between 2003 and 2007. This trend is fueled by phenomenal rise in the oil prices during this period.

In 2000, the country signed a bilateral trade agreement with EU. This agreement enables the country to export goods without paying EU tariff. On parallel lines, Algeria will have to gradually remove tariff barriers on EU imports. Bilateral trade volumes increased by some $9.3 \%$ between 2000 and 2009, principally driven by rising oil exports. With 98\% of EU imports from Algeria in 2009 being energy, Algeria ranked as the EU's fifth largest energy provider (5.1\% of total EU energy imports), for a value of $€ 17.2$ million in 2009. Algeria's main economic trade partners, France as the first exporter of Algeria and US as the first importer of Algeria. The US is the first importer from Algeria by more than $\$ 12.021$ billion in 2010 present 1/4 Algeria exports, and Algeria import 995,8 million from US in the same years. The Principal exports are Crude oil, Natural gas, refined products, and Raw materials. For principal imports: Capital goods, Semi-finished goods, Food stuff, and consumer good. Algeria ranks 42 in the world for its total exports. The trading partner's share of Algeria export in the period between 1981 and 2009 is presented in the figure 1 (see appendix).

Algeria's export trade has almost doubled in the period between 2000 and 2010 . This trend is fueled by phenomenal rise in the oil prices during this period. If the oil prices fall in the future, the Algerian economy will suffer severe revenue deficit. We remark in the graph that the first customer of Algeria exports is US. from 1981 to 1999 US was the first by the share which varies between $20 \%$ and 33\% of Algeria exports, between 2000 to 2009 US imports from Algeria is more than $30 \%$, this because the rise of the oil price and we know that US is the first importer of Algeria hydrocarbon. As per total import, Algeria ranks 53 in the world. The trading partners' share of Algeria import is presented in the figure2 (see appendix). Industrial equipments has the highest share (30\% approximately) in the Algeria's imports.

\subsection{Algeria Dinar Overview}

The management of the Exchange Rate has been a critical issue for the economic policy and researchers, especially in developing countries. Until the end of the Bretton-Woods system in 1973, from January 1974, the exchange rate of 
the Algeria dinar was pegged to a basket of currencies in which the U.S. dollar was assigned a relatively large weight due to its importance in hydrocarbon export receipts and debt-service payments - with adjustments taking place from time to time. The substantial appreciation of the U.S. dollar during the first half of the 1980s led to a strong rise in the real value of the Algeria dinar (of about 50 percent during 1980-85), thus undermining the competitiveness of the nonhydrocarbon, sector and stimulating imports. In 1986, Algeria's economy experienced the reverse oil shock, and the government responded to the dramatic erosion of export revenue by borrowing abroad and intensifying import restrictions. In parallel, the Bank of Algeria let the Algeria dinar depreciate against the basket by 31 percent between 1986 and 1988. Restrictions imposed on the allocation of foreign exchange increased demand for foreign exchange in the informal market, driving the parallel market premium to about 400 percent. This rigid system was replaced in 1988 by a system of foreign exchange allocation to the five public commercial banks within a as part of an attempt to realign domestic relative prices and increase openness, the Bank of Algeria let the dinar depreciate by more than 100 percent to DZD 22 per U.S. dollar. During 1991-94, the rate of nominal depreciation averaged 4 percent annually, bringing the value of the Algeria dinar to about DZD 24 per U.S. dollar on the official market. This relative stability of the nominal rate did not correspond to economic fundamentals: adverse terms of trade shocks and expansionary fiscal and monetary policies resulted in inflation being persistently higher than in Algeria's trading partners. The Algeria dinar, therefore, appreciated by 50 percent in real terms between October 1991 and end-1993.

In 1994, the authorities put in place an adjustment program. One of the immediate objectives of the program was to correct the previous real appreciation of the Algerian dinar. Along with broad trade liberalization measures, including on trade-related payments, a two step devaluation of the Algerian dinar (in total 70 percent) took place between April and September 1994. The spread between the parallel market and official exchange rates fell to about 100 percent during this time. Since 1995, Algeria's exchange rate policy has aimed at maintaining a stable real exchange rate against a basket of currencies weighted according to the country's main trading partners and competitors. In 1995, the managed float regime was implemented through fixing sessions between the Bank of Algeria and commercial banks. Between 1995 and 1998 the REER appreciated by more than 20 percent, followed by a depreciation of 13 percent between 1998 and 2001. Following 16 months of real depreciation since early 2002, due to the appreciation of the euro against the U.S. dollar, the authorities intervened in the foreign exchange market in the second half of 2003 to realign the REER to its end-2002 level instead of its end-1995 level. Between June and December 2003, the Algerian dinar depreciated against the U.S. dollar by $11 \frac{1}{2}$ percent and the REER depreciated by $71 \frac{1}{2}$ percent. Between February 2004 and December 2007, the Algerian dinar depreciates further more against the US dollar. The bank of Algeria continues to operate a managed float of the Algerian dinar. The main aim is to maintain exchange-rate stability particularly with the US dollar and the euro. To curb the rising inflation, bank of Algeria allowed the currency to appreciate against the dollar during 2008 when it averaged DZD65/US\$1. Since then they have allowed the currency to depreciate to around DZD73/US\$1 to reduce the demand for imports. The government is likely to continue to depreciate the currency further in 2010 .

The nominal exchange rate of Algeria dinar (DZD) with the currencies of its trading partners is presented in the figure 3 (see appendix), we can see that the Algerian dinar is almost stable over the period of 1981 to 1990 its about 5DZD against US\$, Euro, in the period between 1991 and 2009 the Algerian Dinar is depreciate very fast against the two currencies (Euro, US\$) for the Euro case Algeria dinar is depreciate from 5DZD/Euro in 1990 to 103 DZD/Euro in 2009, dinar is depreciate against US dollar from 5DZD/US\$ to 80DZD/US\$ for 2004 the Algeria dinar then mark a small appreciation against US\$ the due to US\$ depreciation against Euro.

\section{Data and Methodology}

According to Rose \& Yellen (1989) and the work of Rose (1991) Bahmani-Oskooee (1991) studies, the country's trade balance behavior is built into a reduced form function directly depending on the real effective exchange rate (REER), foreign income(GDP) or (Y*) and real domestic income(GDP) or (Y).

$$
\begin{array}{r}
\mathrm{TB}_{\mathrm{i}}=\mathrm{TB}_{\mathrm{i}}\left(\mathrm{REER}, \mathrm{Y}_{\mathrm{i}}^{*}, \quad \mathrm{Y}\right) \\
(+/-) \quad(+/-)(+/-)
\end{array}
$$

All our variables are transformed to natural logarithm that we verify the characteristics of partial elasticity in the short and long run and also to work with the hypothesis of variation rate rather than the variables at level. The quarterly data utilized for our study was selected from the International Financial Statistics (IMF-IFS-CDROM), (IMF-DOT-CDROM) published by the International Monetary Fund (IMF) March 2008, covering the whole period 1981-2008 (see appendix). 


\subsection{Model Specification}

This study attempts to develop a similar model applied by Singh (2002) and Rose (1991) in their studies that the trade balance is a function of real effective exchange rate and the domestic and foreign real income. A log-linear specification of the model can be stated as follows:

$$
\text { Ln } \mathrm{TB}_{\mathrm{it}}=\omega_{0}+\omega_{1} \operatorname{Ln} \mathrm{REER}_{\mathrm{t}}+\omega_{2} \mathrm{LnY}_{\mathrm{t}}+\omega_{3} \operatorname{LnY}_{\mathrm{it}}{ }^{*}+\varepsilon_{\mathrm{t}}
$$

i: country trading partner (US, France), or the rest of world and t: time

Where Ln REERt, LnYt, LnYit* are logarithm of real effective exchange rate, real domestic income, and real income of major trading partners or the real income of rest of world, and ln represents natural logarithm, et is assumed to be a white-noise process, and trade balance, $\mathrm{TB}_{\mathrm{it}}$, represents as the ratio of exports to imports of Algeria with country $\mathrm{i}$. We focus on the trade ratio the value of exports to the value of imports, $\mathrm{X} / \mathrm{M}$, for empirical purposes. One major reason for its use is that it is possible to use the log on this variable, regardless of whether exports are greater or less than imports. In this research, real effective exchange rate, REERt, represents the price of a representative basket of Algeria's all trading partners' currencies, and $\mathrm{Y}_{\mathrm{it}}{ }^{*}$ expresses as gross domestic product of country $\mathrm{i}$.

Following classical theory, Marshall-Lerner theory holds when $\omega_{1}$ is positive $\left(\omega_{1}>0\right)$ indicating that depreciation leads to improve the trade balance for Algeria. However in short-run we expect $\omega_{1}$ to be negative $\left(\omega_{1}<0\right)$.

The theoretical notion suggests that the exports and imports increases as the real income of the trade partners and domestic income rises respectively, and vice versa. In that case we could expect $\omega_{2}<0$ and $\omega_{3}>0$. However, imports may decline as income increases if the real income rises due to an increase in the production of import-substitute goods, or due to the rise in productive capacity, and in that case we would expect $\omega_{2}>0$ and $\omega_{3}<0$.

\subsection{Estimation Methods}

The first step is an attempt to examine the variables of the model whether all of them are the same order of integration. We run the univariate augmented Dickey-Fuller (ADF) and Phillip-Peron (PP) unit root tests for each variable, testing for the significance of trend and no trend with non-stationary.

After performing the unit root test, the study proceeded to test the long-run relationship among the variables used in the balance of trade regression equation, named cointegration test in order to determine the number of cointegrating vectors for different combinations of variables. We carried the Johansen multivariate approach (cointegration test technique) using Trace Statistic and Maximum Eigenvalue statistic.

The short-run dynamics of the balance of trade of Algeria was estimated following general-to-specific modeling approach. Given that all variables are in their first difference, we restricted the lag structure to two (2) periods. Insignificant lags were eliminated sequentially. We employed the error-correction model (ECM) can be expressed and estimated with a more appropriate simple dynamic representation of the (ECM) equation (2). Thus, an error correction term lagging one period error-correction term ECTt-1 is included as one of the independent variables in the general over parameterized error correction model of maximum sustainable yield equation. This term capture the long run relationship by attempt to correct deviations from the long run equilibrium path. Its coefficient can be interpreted as the speed of adjustment or the amount of disequilibrium transmitted each period to amount of trade balance $(\operatorname{lnTB})$.

$$
\begin{gathered}
\Delta \operatorname{LnTB}_{\mathrm{it}}=\beta_{0}+\sum_{\mathrm{j}=1}^{\mathrm{p}} \delta_{\mathrm{j}} \Delta \operatorname{LnTB}_{\mathrm{it}-\mathrm{j}}+\sum_{\mathrm{j}=0}^{\mathrm{p}} \lambda_{\mathrm{j}} \Delta \operatorname{LnY}_{\mathrm{t}-\mathrm{j}}+\sum_{\mathrm{j}=0}^{\mathrm{p}} \varphi_{\mathrm{j}} \Delta \operatorname{LnY}^{*}{ }_{\mathrm{it}-\mathrm{j}}+ \\
\sum_{\mathrm{j}=0}^{\mathrm{p}} \emptyset_{\mathrm{j}} \Delta \operatorname{LnREER}_{\mathrm{t}-0}+\psi \mathrm{EC}_{\mathrm{t}-1}+\varepsilon_{\mathrm{t}}
\end{gathered}
$$

Where: $\mathrm{EC}_{\mathrm{t}-1}=\left[\mathrm{LnTB}_{\mathrm{it}-1}-\omega_{0}-\dot{\omega}_{1} \mathrm{LnY}_{\mathrm{t}-1}-\omega_{2} \mathrm{LnY}^{*}{ }_{\mathrm{it}-1}-\omega_{3} \operatorname{LnREER}_{\mathrm{t}-1}\right]$, and $\psi$ measures the adjustment speed between the short-run and long-run disequilibrium.

Then we perform the Granger-Causality test in order to examine the short-run relations among the four variables used in balance of trade regression equation in other word this test is done to see the short run causality running from independent variable, to the dependent variable. To solve this problem, we utilize the technique developed by Granger (1969) and improve later by Sims (1972). The relationship between those variables can be captured by a VAR model.

Then, if we want to test whether $X_{t}$ causes $Y_{t}$, we analyze that how much of the present $Y_{t}$ can be illustrated by lagged values of $Y_{t}$ and $X_{t}$. In the Granger causality we test null hypothesis that $X_{t}$ does not granger cause $Y_{t}$; and if we can reject the null hypothesis, it means that $X_{t}$ does Granger cause $Y_{t}$. So the bivariate regression form for the Granger causation is written as follows:

$$
\begin{gathered}
\mathrm{Y}_{\mathrm{t}}=\lambda_{0}+\sum_{\mathrm{i}=1}^{\mathrm{l}} \lambda_{\mathrm{i}} \mathrm{Y}_{\mathrm{t}-\mathrm{i}}+\sum_{\mathrm{i}=1}^{1} \mu_{\mathrm{i}} \mathrm{X}_{\mathrm{t}-\mathrm{i}}+\mathrm{v}_{\mathrm{t}} \\
\mathrm{X}_{\mathrm{t}}=\lambda_{0}+\sum_{\mathrm{i}=1}^{1} \lambda_{\mathrm{i}} \mathrm{X}_{\mathrm{t}-\mathrm{i}}+\sum_{\mathrm{i}=1}^{1} \mu_{\mathrm{i}} \mathrm{Y}_{\mathrm{t}-\mathrm{i}}+\varepsilon_{\mathrm{t}}
\end{gathered}
$$


Finally the dynamic behavior of our model can be analyzed using: IRF to show if there is evidence of the J-curve hypothesis in all cases of study.

\section{Empirical Results and Interpretations}

\subsection{Unit Root Test}

The results over the period are reported in table-1 (see appendix)

According to ADF test, PP test all variables are not stationary at level. We differenced the data and run our test again, as a result the hypothesis of nonstationarity or presence of unit root is rejected at 99 percent level of confidence; for all variables, so all variables are integrated in order I(1) in all cases. The multiple individual time-series variables are found to be integrated of order one.

Where TB is the total trade balance of Algeria, and $\mathrm{LTB}_{\mathrm{Alg}-U \mathrm{US}} \mathrm{LTB}_{\mathrm{Alg} \text {-Fran }}$ present the Algeria bilateral trade balance with US and France respectively $\mathrm{Y}$ is the GDP of Algeria, $\mathrm{Y}_{\mathrm{w}}$ is the world GDP, $\mathrm{Y}_{\text {Fra }}$ present the GDP of France, and $\mathrm{Y}_{\mathrm{US}}$ is the US GDP.

\subsection{Cointegration Test \& Error Correction Model}

According to the table-2 in appendix, Both the "trace statistic" and "eigenvalue test" lead to the rejection of the null hypothesis of none coitegrating vectors against the alternative hypothesis of (one or more cointegrating vectors) at $5 \%$ level of significance for all model (Alg-US, Alg-Fra and Alg-world).

Table- 3 in appendix presents the results of long run cointegrating vector coefficient of the trade balance model. Based on the estimated cointegrating vector and after normalizing our variables by the trade balance, the long-run equilibrium equation can be written as:

- $\quad$ Algeria-France case:

$\mathrm{LnTBt}=-32.71604+0.199907 \mathrm{LnREERt}-0.579529 \mathrm{LnYt}+10.79883 \mathrm{LnYt}{ }^{*}-0.07$ Trend

$$
\text { (0.10160) (0.21618) (2.93385) }
$$

Where $\mathrm{Yt}^{*}$ is the GDP of France, TBt is the Algeria bilateral trade balance with France.

- $\quad$ Algeria-US case:

$\mathrm{LnTBt}=-40.36075+2.218097 \mathrm{LnREERt}-0.59549 \mathrm{LnYt}+6.15612 \mathrm{LnYt}{ }^{*}-0.15$ Trend

$$
\begin{array}{lll}
(0.60298) \quad(0.29892) \quad(2.48363)
\end{array}
$$

Where $\mathrm{Yt}^{*}$ is the GDP of US, TBt is the Algeria bilateral trade balance with US.

- Algeria-world:

LnTBt $=-45.26725+1.707153 \mathrm{LnREERt}-1.149773 \mathrm{LnYt}+3.102719 \mathrm{LnYt} *-0.06 \mathrm{Trend}$

$$
\begin{array}{lll}
(0.49867) \quad(0.56988) & (0.64720)
\end{array}
$$

Where $\mathrm{Yt}^{*}$ is the World GDP, TBt is the Algeria's total trade balance with all its major trading partners (rest of world).

In our study according to the equations above the real domestic income has significant and negative impact on the trade balance for all models (Algeria-US, Algeria-France and Algeria-world), this due to when national incomes rise, the residents demand a great amounts of goods and services because Algeria's is very dependent on its import abroad, and imports is composed especially in consumption goods (food materials, transport equipment, medical product,.....) and capital goods, so any augmentation on the domestic income lead to more imports leading to the deterioration in trade balance.

Foreign income has significant positive impact on the trade balance for all cases this due to, the rise in foreign income increase the demand for Algeria's exports because both US and France are industrialized countries so when their income rise the demand for output will be increased this leads to increase their production, this in turn rise their demand for Algeria's exports (especially raw materials, energy).

According to equations, in the long-run the real depreciation has a significant positive impact on bilateral trade balance of Algeria with respect to US and France, and also REER shows a significant positive impact on Algeria's total trade balance. These results due to the fact that in the long run the volume effect dominate the value effect, which lead to improve trade balance so, devaluation will improve the trade balance in the long-run, this mean that the Marshall-Lerner condition is held in long-run for all cases of our study. 


\subsection{Error Correction Model (ECM)}

$$
\text { Algeria-US } \begin{aligned}
\Delta \mathrm{Ln} \text { TBt } & =-0.2524-0.3177 \Delta \mathrm{Ln} \text { TBt }-1-0.8983 \Delta \mathrm{Ln} \text { REERt-2 } \\
& -4.2925 \Delta \mathrm{Ln} \text { Yt-1 }+12.951 \Delta \mathrm{Ln} \mathrm{Y} * \mathrm{t}-1-0.2359 \text { EC Tt-1 }
\end{aligned}
$$

Algeria-France

$$
\begin{aligned}
\Delta \mathrm{Ln} \text { TBt }= & -0.0998-0.0965 \Delta \mathrm{Ln} \text { TBt }-1-0.9254 \Delta \mathrm{Ln} \text { REERt-2 } \\
& -2.2261 \Delta \mathrm{Ln} \mathrm{Yt}-1+2.2261 \Delta \mathrm{Ln} \mathrm{Y} * \mathrm{t}-2-0.214 \mathrm{EC} \mathrm{Tt}-1
\end{aligned}
$$

Algeria-world

$$
\begin{aligned}
\Delta \text { Ln TBt }= & -0.0577-0.2343 \Delta \text { Ln TBt }-2-0.6409 \Delta \text { Ln REERt-2 } \\
& -0.1988 \Delta \text { Ln Yt-2+0.2421 } \Delta \text { Ln Y*t-2 }-0.381 \text { EC Tt-1 }
\end{aligned}
$$

According to the table-4 in appendix and the equations above, the short-run dynamic estimate suggests that two-period lag REER shows a negative and significant impact on trade balance for all cases, which indicate that the REER depreciation has significant negative impact on trade balance in short-run. The trade balance deteriorates initially after depreciation and some time along the way it starts to improve until it reaches its long-run equilibrium; this time lag comes about as an impact of several lags such as recognition, decision, delivery, replacement and production following a real depreciation. The estimate suggests also that the one-period lag domestic income has significant and negative impact on the bilateral trade balance of Algeria with respect to France and US, means that the change in domestic income in the previous period has an effect on temporary trade balance, for Algeria-world case we see that the two-period lag domestic income has a negative and significant impact on temporary trade balance. The two-period lag foreign income $\left(\mathrm{Y}^{*}\right)$ shows a significant and positive impact on the total trade balance and in the bilateral trade balance of Algeria with France; the change in the US income in the previous period has a positive and significant impact on the temporary bilateral trade balance of Algeria with respect to US. We see also that the trade balance change in the previous period has a negative and significant effect on temporary trade balance in both cases Algeria with respect to France and US; in the case of Algeria-world we see that the two-lag period of trade balance has a negative and significant impact on the temporary trade balance.

The result displays coefficient of ECt-1(speed of adjustment) has a correct sign (negative) meaningful and relatively higher (ECt-1) coefficient (-0.2359), (-0.214) for the case of Algeria with US and France respectively, and higher coefficient $(-0.381)$ in the case of Algeria with world. These signify that the adjustment process to an exogenous shock is rather higher. In other words there is a rapid speed of adjustment back to the equilibrium. This test suggests that real effective exchange rate, and all other variables have a significant impact on balance of trade in the short-run for all cases of the study.

\subsection{Granger Causality Test (Result and Interpretation)}

Results report in the table-5 in appendix, Granger Causality test shows that causality goes unidirectionally from Real Effective Exchange Rate (REER), foreign income ( $\left.\mathrm{Y}^{*}\right)$, and domestic income (Y) to Trade Balance (TB).

\subsection{Impulse Response Analysis}

According to the (figure I, II, III) in appendix J-curve effect is observed for Algeria in its bilateral trade with the US. A real effective exchange rate shock initially worsened Algeria's real trade balance with respect to the US. The deterioration lasts for 2 quarters, after the trade balance improved before falling again to a value lower than the initial value. Beyond 5 quarters there is an improvement as the trade balance settles to a new long run equilibrium level which is largely higher than the initial value, the improvement is about $9 \%$.

A weak form of J-curve is observed for Algeria in its bilateral trade with France.

a J-curve effect is observed for Algeria in its total trade balance. A real effective exchange rate shock initially worsened Algeria's real trade balance. The deterioration lasts for 2 quarters, after which the trade balance improved before falling again, after 4 quarter it improved by about $1 \%$ then it slightly deteriorate until the 12 quarters. Beyond 12 quarters the trade balance settles to a new long run equilibrium level which is higher than the initial value, the improvement is about $0.5 \%$.

\section{Conclusion}

In this paper we assess the long and short run effects of real effective exchange rate (REER) on the Algeria's trade balance (TB) and Algeria's bilateral trade balance with US and France in a long period from 1981Q1 to 2009Q4. The 
base model for each case includes the log of bilateral trade ratio (exports/imports), the log of real effective exchange rate, and the log of real domestic and foreign income.

The Johansen test confirms the presence of a long run cointegrating relationship among the variables used for this study. The study also reveals that the real effective exchange rate has a significant positive impact on Algeria's bilateral trade balance with US and France, and on Algeria's total trade balance in long-run, and it has significant negative impact on trade balance for all cases in the short-run. We find that in long-run the effect of REER in case of bilateral trade balance is more significant with the major export partner (US) than with major import partner (France).

The Granger Causality test shows that causality goes unidirectionally from Real Effective Exchange Rate (REER), foreign income $\left(\mathrm{Y}^{*}\right)$, and domestic income (Y) to Trade Balance (TB); Granger causality test confirms the causal relation between exchange rate and bilateral trade balance with respect to US and France, it affirms also the causal relation between exchange rate and total balance of trade of Algeria; so the real effective exchange rate help in predicting the trade balance.

It can be conclude that real depreciation has a long-run positive impact on the total trade balance of Algeria, and on Algeria bilateral trade balance with respect to US, we find in both cases the evidence of J-curve hypothesis. In the case of Algeria-France we observed a weak form of J-curve. Overall, the results of the generalized impulse response analyses suggest that the Marshall-Lerner condition holds in the long run with varying degree of J-curve effects in the short run.

In all, we get the overall conclusion that the devaluation of Algeria's currency as a whole seems to be beneficial for Algeria's trade.

\section{References}

Ahmed, N. (2000). Export response to trade liberalization in Bangladesh: a cointegration analysis. Applied Economics, 32, 1077-1084. http://dx.doi.org/10.1080/000368400322138

Asian Development Bank (ADB). (2006). Asian Development Outlook 2006 Update, p. 47.

Aziz, M. N. (2003, October). Devaluation: Impact on Bangladesh Economy. The Cost and Management, September-October, 16-21.

Bahmani-Oskooee, M. (1995). Real and nominal effective exchange rates for 22 LDCs: 1971:1 - 1990:4. Applied Econometrics, 27, 591-604. http://dx.doi.org/10.1080/00036849500000048

Bhattarai, D. K., \& Armah, M. K. (2005). The Effects of Exchange Rate on the Trade Balance in Ghana:Evidence from Cointegration Analysis. Cottingham United Kingdom: Centre for Economic Policy Business School, University of Hull Cottingham.

David, M. G., \& Guadalupe, F. Á.-U. (2006). Exchange Rate Policy and Trade Balance.A cointegration analysis of the argentine experience since 1962. Munich Personal RePEc Archive Paper No. 151

Dickey, D., \& Fuller, W. (1979). Distribution of the Estimators for Autoregressive Time Series with a Unit Root. Journal of the American Statistical Association, 74, 427-431.

Fleming, J. (1962). Domestic Financial Policies under Fixed and under Floating Exchange Rates. IMF staff paper 9 , (November) 369-379.

Granger, C. W. (1969). Investigating causal relations by econometric models and cross-spectral methods. Econometrica, 37, 424-438. http://dx.doi.org/10.2307/1912791

Gomes, F. A., \& Paz, L. S. (2005). Can real exchange rate devaluation improve trade balance?. The 1990-1998 Brazilian case. Applied Economics Letters, 12, 525-528. http://dx.doi.org/10.1080/13504850500076908

Islam, M. (2003). Exchange Rate Policy of Algeria - Not Floating Does Not Mean Sinking. Keynote Paper presented at dialogue organized by Centrefor Policy Dialogue, Algeria - January 2, 2003.

Johansen, S. (1988). Statistical Analysis of Cointegrating Vectors. Journal of Economic Dynamics and Control, 231-54. http://dx.doi.org/10.1016/0165-1889(88)90041-3

Juselius, K. (1990). Maximum likelihood estimation and inference on cointegration- with application to the demand for money. Economics and Statistics, 52, 169-210. Oxford Bulletin of Statistics.

Mussa, M. (2002). Exchange Rate Regimes in an Increasingly Integrated World Economy. Washington DC: International Monetary Fund Occasional Paper 193. 
Narayan, P. K. (2004). New Zealand's trade balance: evidence of the J-Curve and granger causality. Applied Economics Letters, 11, 351-354. http://dx.doi.org/10.1080/1350485042000228187

Nusrate, A. (2008). The Role of Exchange Rate in Trade Balance: Empirics from Bangladesh. University of Birmingham, UK.

Onafowora. O. (2003). Exchange rate and trade balance in East Asia: is therea J-Curve? Economics Bulletin, 5(18), $1-13$.

Phillips-Perron. (1988). Testing for a Unit Root in Time Series Regression. Biometrika, 75, $335-346$. http://dx.doi.org/10.1093/biomet/75.2.335

Rose, A. K. (1991). The role of exchange rate in a popular model of international trade: Does the Marshall-Lerner condition hold? Journal of International Economics, 30, 301-316. http://dx.doi.org/10.1016/0022-1996(91)90024-Z

Singh, T. (2002). India's trade balance: the role of income and exchange rates. Journal of Policy Modeling, 24, 437-452. http://dx.doi.org/10.1016/S0161-8938(02)00124-2

Tavlas, S. (2003). The Economics of Exchange Rate Regimes: A Review Essay. Oxford: Blackwell Publishing Ltd.

Tsen, W. H. (2006). Is there a long-run relationship between trade balance and terms of trade? The case of Malaysia. Applied Economics Letters, 13, 307-311. http://dx.doi.org/10.1080/13504850500393428

Wickham, P. (1985). The Choice of Exchange Rate Regime in Developing Countries. IMF Staff Papers, 32(2), 248-28. http://dx.doi.org/10.2307/3866841

\section{Notes}

Note 1. Null hypothesis for Augmented Dickey-Fuller (ADF) and Phillips-Perron (PP) is the series has a unit root (non-stationary). The critical values for ADF are -3.65 (without trend), -4.26 (with trend) at 1\%, -2.96 (without trend) -3.56 (with trend) at 5\% and -2.62 (without trend), -3.21 (with trend) at $10 \%$ level of significance. The critical values for PP test are -2.58 (without trend), -4.04 (with trend) at 1\%, -1.94 (without trend) -3.44 (with trend) at $5 \%$ and -1.61 (without trend), -3.15 at 10\% level of significance which have been tabulated from Mackinnon (1996) one-sided p-values.

Note 2. I $n$ table $4: *$ indicate the independent variable is significant a $10 \%, * *$ indicate the significant at $5 \%$ and $* * *$ refers to the significant a $1 \%$ level.

Note 3. I $n$ the table 5: the F-statistic values of overall significance are given in the table. Number of observations is given in parenthesis. $* * *$ and $* * *$ indicate the rejection of the null hypothesis that vertical variable does not cause the respective horizontal variable to change, or vertical variables cannot help in predicting the horizontal variables at $10 \%, 5 \%$ and $1 \%$ level of significance respectively. Vars: variables.

Table 1. Stationary test for the fundamentals: ADF and PP tests

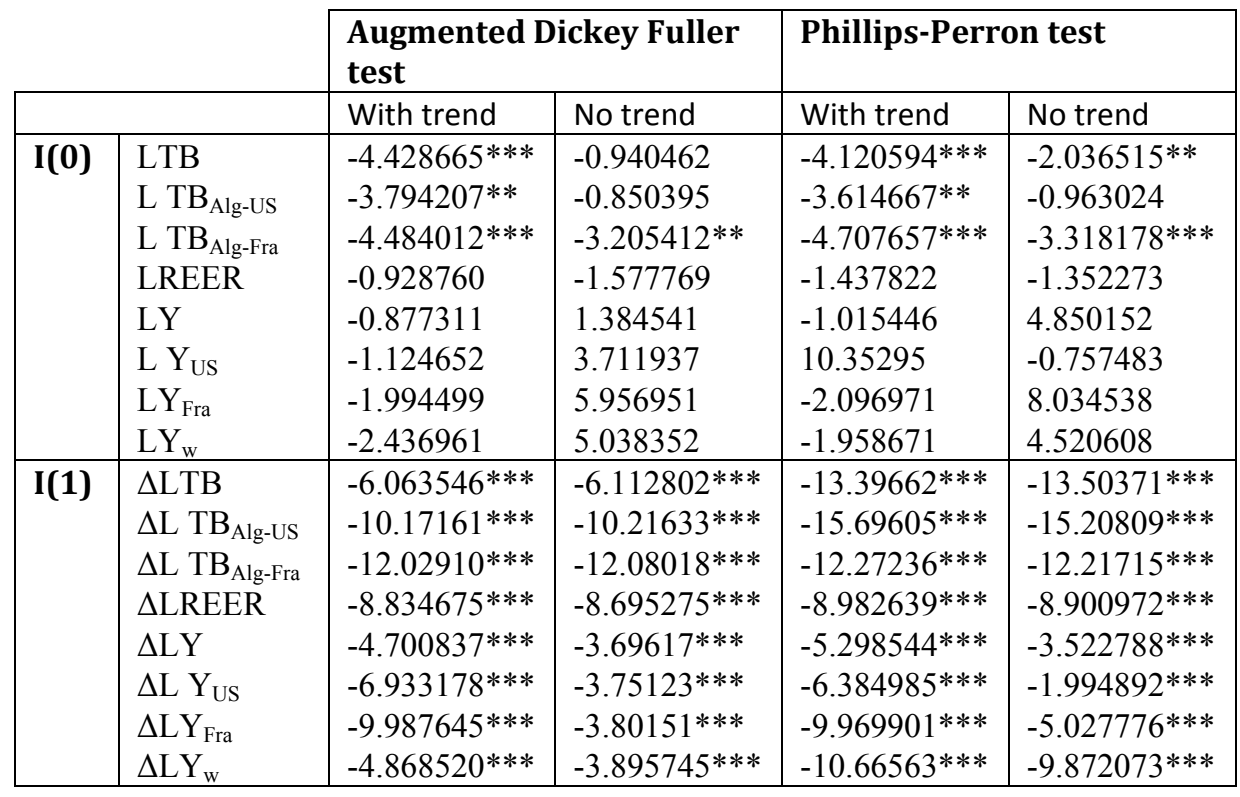


Table 2. Johansen's cointegration test (Sample: 1981Q1- 2009Q4)

\begin{tabular}{|l|l|l|l|l|l|l|}
\hline Cases & \multirow{2}{*}{$\begin{array}{l}\text { Null } \\
\text { hypothesis }\end{array}$} & $\begin{array}{l}\text { Alternative } \\
\text { Hypothesis }\end{array}$ & \multicolumn{2}{|l|}{ Trace test } & \multicolumn{2}{l|}{$\begin{array}{l}\text { Maximal Eigenvalue } \\
\text { test }\end{array}$} \\
\cline { 4 - 7 } & & & Statistics & $\begin{array}{l}5 \% \\
\text { Critical } \\
\text { value }\end{array}$ & Statistics & $\begin{array}{l}5 \% \\
\text { Critical } \\
\text { value }\end{array}$ \\
\hline Alg/US & $\mathrm{r}=0$ & $\mathrm{r}=1$ & $65.10985^{*}$ & 55.24578 & $33.48059^{*}$ & 30.18507 \\
& $\mathrm{r} \leq 1$ & $\mathrm{r}=2$ & 31.62926 & 35.01090 & 16.85229 & 24.25202 \\
& $\mathrm{r} \leq 2$ & $\mathrm{r}=3$ & 14.77697 & 18.3977 & 13.51983 & 17.14769 \\
& $\mathrm{r} \leq 3$ & $\mathrm{r}=4$ & 1.257139 & 3.841466 & 1.257232 & 3.841466 \\
\hline Alg/Fra & $\mathrm{r}=0$ & $\mathrm{r}=1$ & $59.34656^{*}$ & 55.24578 & $33.81507 *$ & 30.18507 \\
& $\mathrm{r} \leq 1$ & $\mathrm{r}=2$ & $36.19700^{*}$ & 35.01090 & 20.18791 & 24.25202 \\
& $\mathrm{r} \leq 2$ & $\mathrm{r}=3$ & 16.00909 & 18.3977 & 12.06065 & 17.14769 \\
& $\mathrm{r} \leq 3$ & $\mathrm{r}=4$ & 3.648443 & 3.841466 & 3.239845 & 3.841466 \\
\hline Alg/world & $\mathrm{r}=0$ & $\mathrm{r}=1$ & $75.97823^{*}$ & 63.87610 & $40.55284^{*}$ & 32.11832 \\
& $\mathrm{r} \leq 1$ & $\mathrm{r}=2$ & 35.42540 & 42.91525 & 24.02090 & 25.82321 \\
& $\mathrm{r} \leq 2$ & $\mathrm{r}=3$ & 11.00450 & 25.87211 & 6.934270 & 19.38702 \\
& $\mathrm{r} \leq 3$ & $\mathrm{r}=4$ & 4.070277 & 12.51798 & 4.070227 & 12.51798 \\
\hline
\end{tabular}

Table 3. Estimated coefficients derived by normalizing on $\ln \mathrm{TB}$

\begin{tabular}{|l|l|l|l|l|l|l|}
\hline Country & LnTB & $\operatorname{lnREER}$ & $\ln \mathrm{ln}$ & $\ln \mathrm{F}^{*}$ & $\mathrm{C}$ & Trend \\
\hline Alg/Fra & 1.00000 & 0.199907 & -0.579529 & 10.79883 & -32.71604 & -0.078041 \\
& & $(0.10160)$ & $(0.21618)$ & $(2.93385)$ & & $(0.04827)$ \\
& & {$[1.96755]$} & {$[-2.68077]$} & {$[3.68077]$} & & {$[-1.61687]$} \\
\hline Alg/US & \multirow{2}{*}{1.00000} & 2.218097 & -0.59549 & 6.156112 & -40.36075 & -0.150745 \\
& & $(0.60298)$ & $(0.29892)$ & $(2.48363)$ & & \\
& & {$[3.67854]$} & {$[-1.99210]$} & {$[2.47867]$} & & \\
\hline Alg/World & 1.00000 & 1.707153 & -1.149773 & 3.102719 & -45.26725 & -0.063814 \\
& & $(0.49867)$ & $(0.56988)$ & $(0.64720)$ & & $(0.02082)$ \\
& & {$[3.42342]$} & {$[-2.01757]$} & {$[4.79405]$} & & {$[-3.04643]$} \\
\hline
\end{tabular}


Table 4. Estimated ECM

\begin{tabular}{|l|l|l|l|}
\hline Model & Independent variables & Coefficient & Standard error \\
\hline Algeria-US & C(Constant) & $-0.2524^{* * *}$ & 0.095 \\
& $\Delta$ Ln TBt-1 & $-0.3177^{* * *}$ & 0.112 \\
& $\Delta$ Ln REERt-2 & $-0.8983^{* * *}$ & 0.235 \\
& $\Delta$ Ln Yt-1 & $-4.2925^{*}$ & 2.263 \\
& $\Delta$ Ln Y*t-1 & $12.951^{* *}$ & 6.593 \\
& EC Tt-1 & $-0.2359^{* * *}$ & 0.086 \\
\hline Algeria-France & C(Constant) & $-0.0998^{*}$ & 0.059 \\
& $\Delta$ Ln TBt-1 & $-0.0965^{* * *}$ & 0.038 \\
& $\Delta$ Ln REERt-2 & $-0.9254^{* * *}$ & 0.145 \\
& $\Delta$ Ln Yt-1 & $-2.2261^{* * *}$ & 0.825 \\
& $\Delta$ Ln Y*t-1 & $2.226^{* *}$ & 0.841 \\
& EC Tt-1 & $-0.214^{* * *}$ & 0.051 \\
\hline Algeria-World & C(Constant $)$ & $-0.0577^{* *}$ & 0.025 \\
& $\Delta$ Ln TBt-2 & $0.2343^{* * *}$ & 0.083 \\
& $\Delta$ Ln REERt-2 & $-0.6409^{* * *}$ & 0.248 \\
& $\Delta$ Ln Y*t-2 & $0.4210^{*}$ & 0.251 \\
& $\Delta$ Ln Yt-2 & $-0.1988^{*}$ & 0.108 \\
& EC Tt-1 & $-0.381^{* * *}$ & 0.068 \\
\hline
\end{tabular}

Table 5. Pairwise Granger Causality test (F-statistic; sample: 1981Q1-2009Q4; lags: 2)

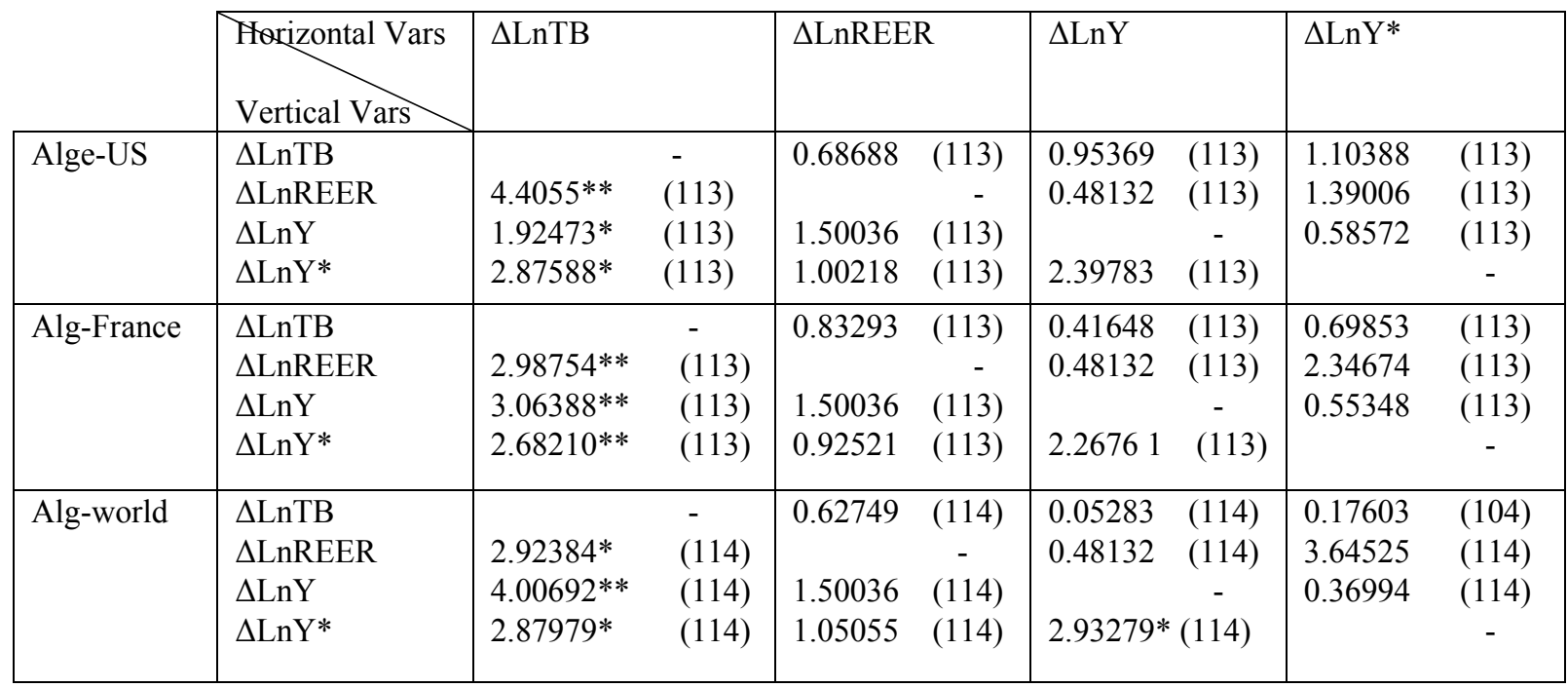

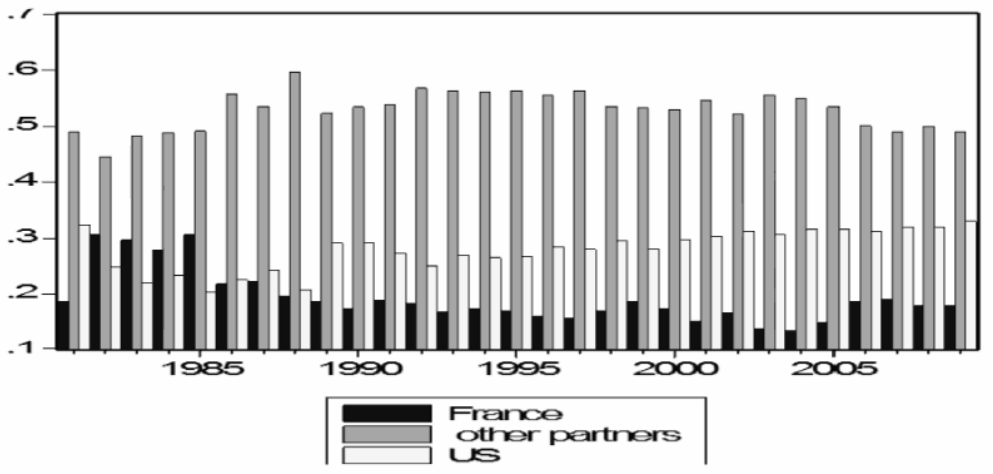

Figure 1. Trading partners Share in Algeria's exports, annually basis (1981 -2009) 


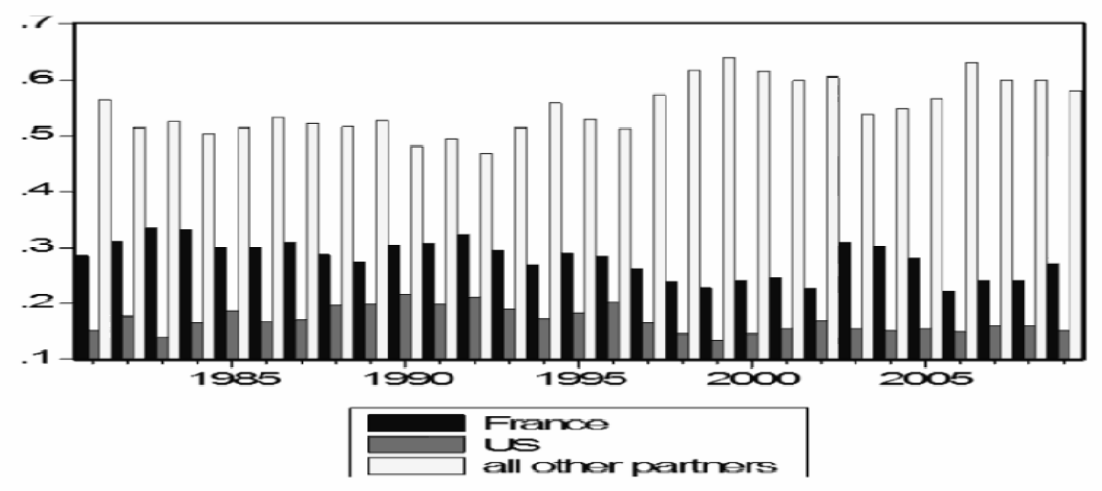

Figure 2. Trading partners share in Algeria's imports, annually basis (1981 -2009)

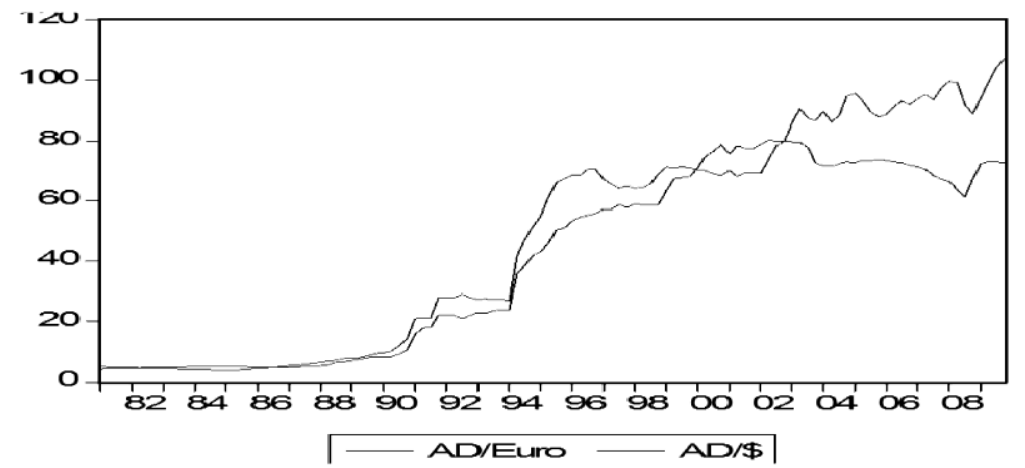

Figure 3. The Algerian dinar nominal exchange rate, quarterly basis (1981Q1 -2009Q2)

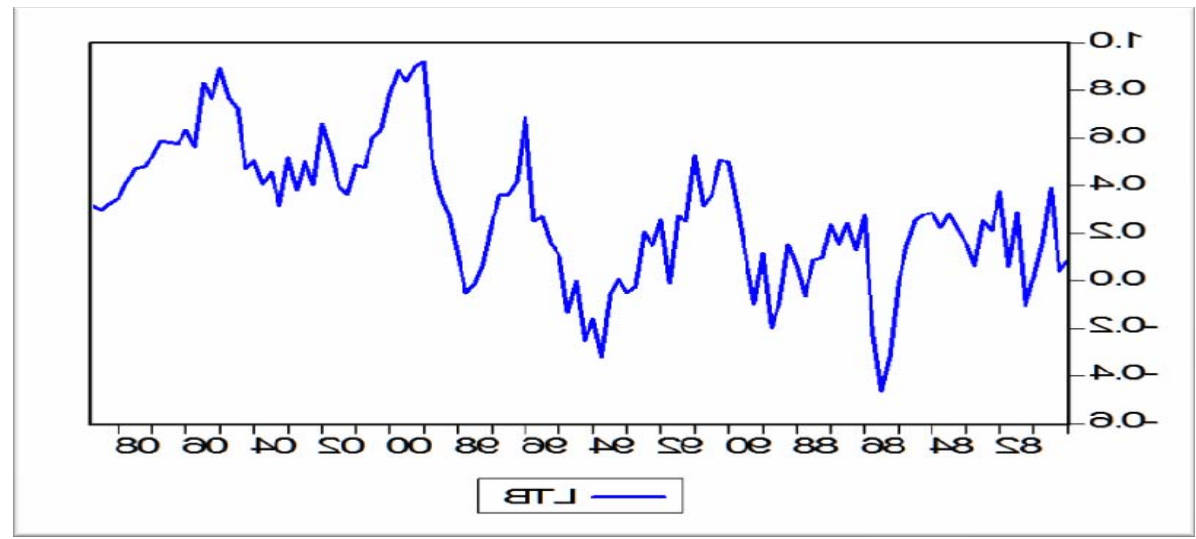

Figure 4. Total trade balance of Algeria, quarterly basis (1981Q1 -2009Q4) 


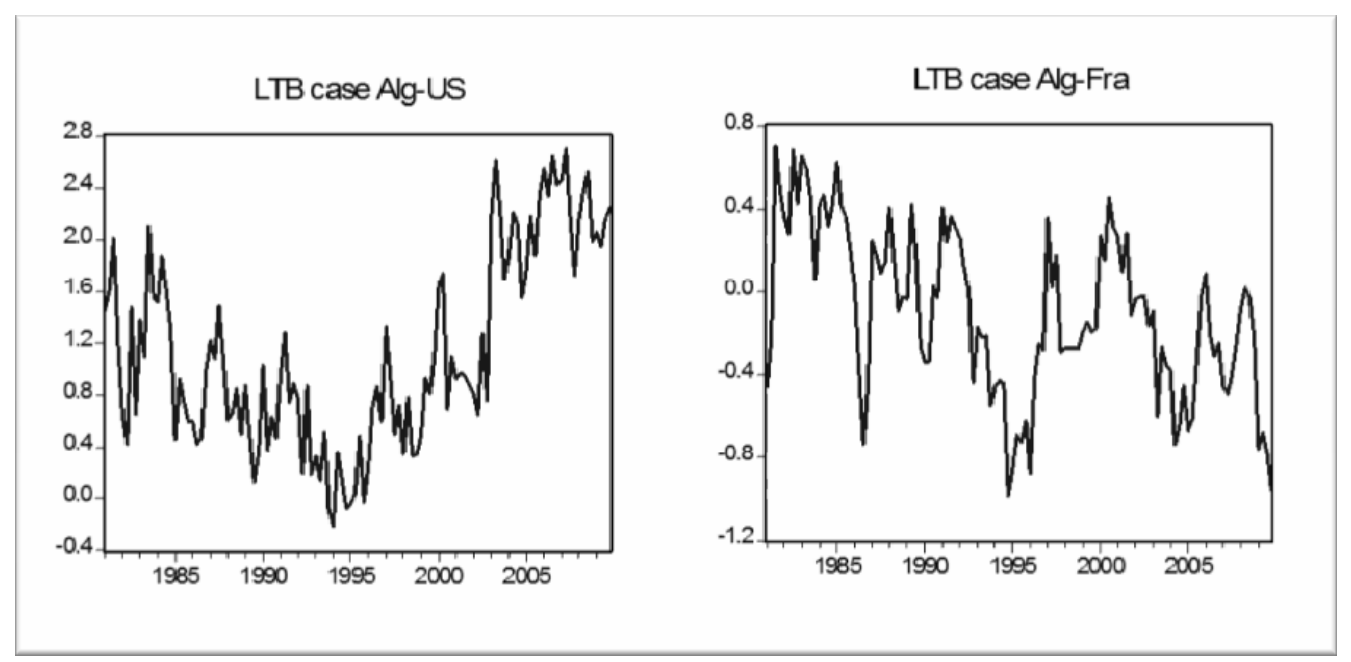

Figure 5. Trade balance of Algeria with its two trading partners, quarterly basis (1981Q1 -2009Q4)

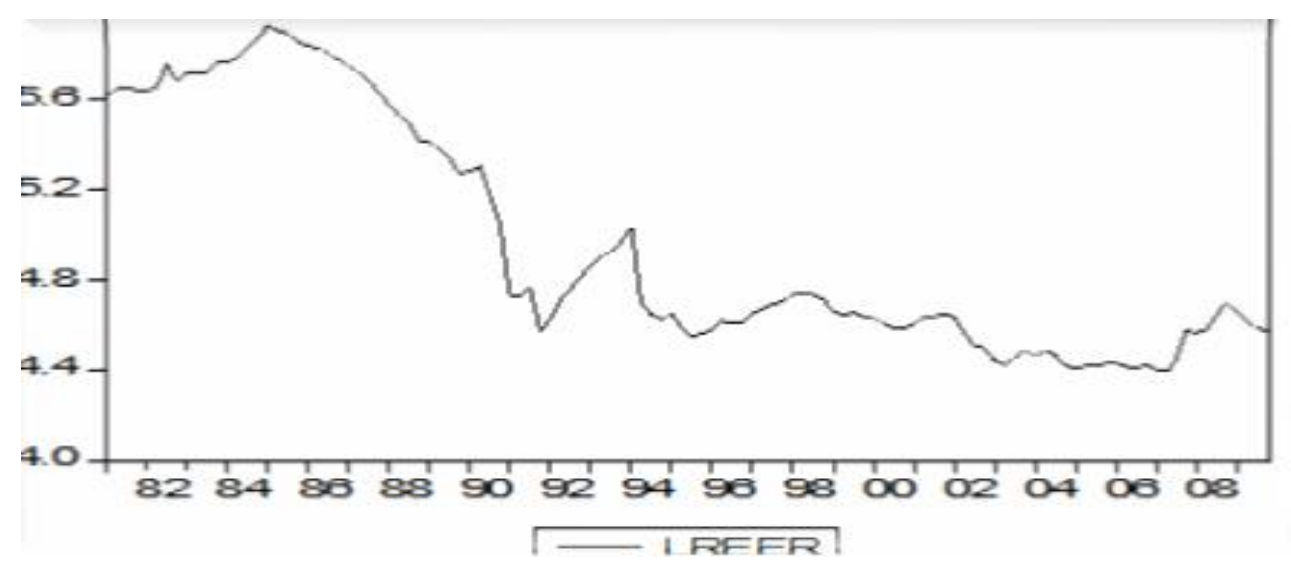

Figure 6. Real effective exchange rate, quarterly basis (1981Q1-2009Q4)

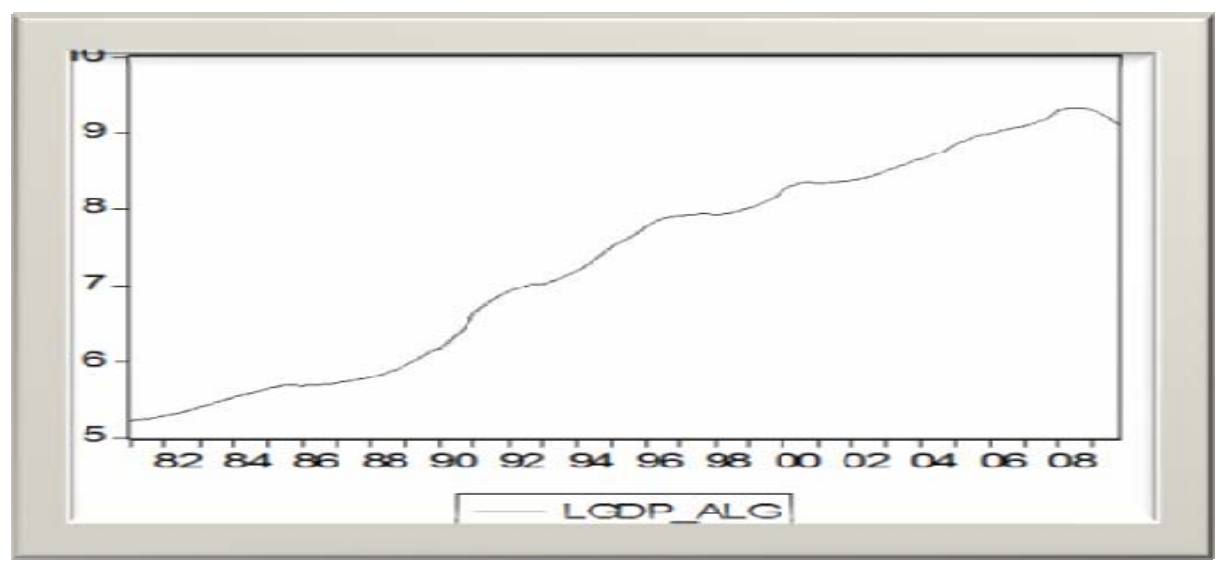

Figure 7. Domestic income, quarterly basis (1981Q1 -2009Q4) 

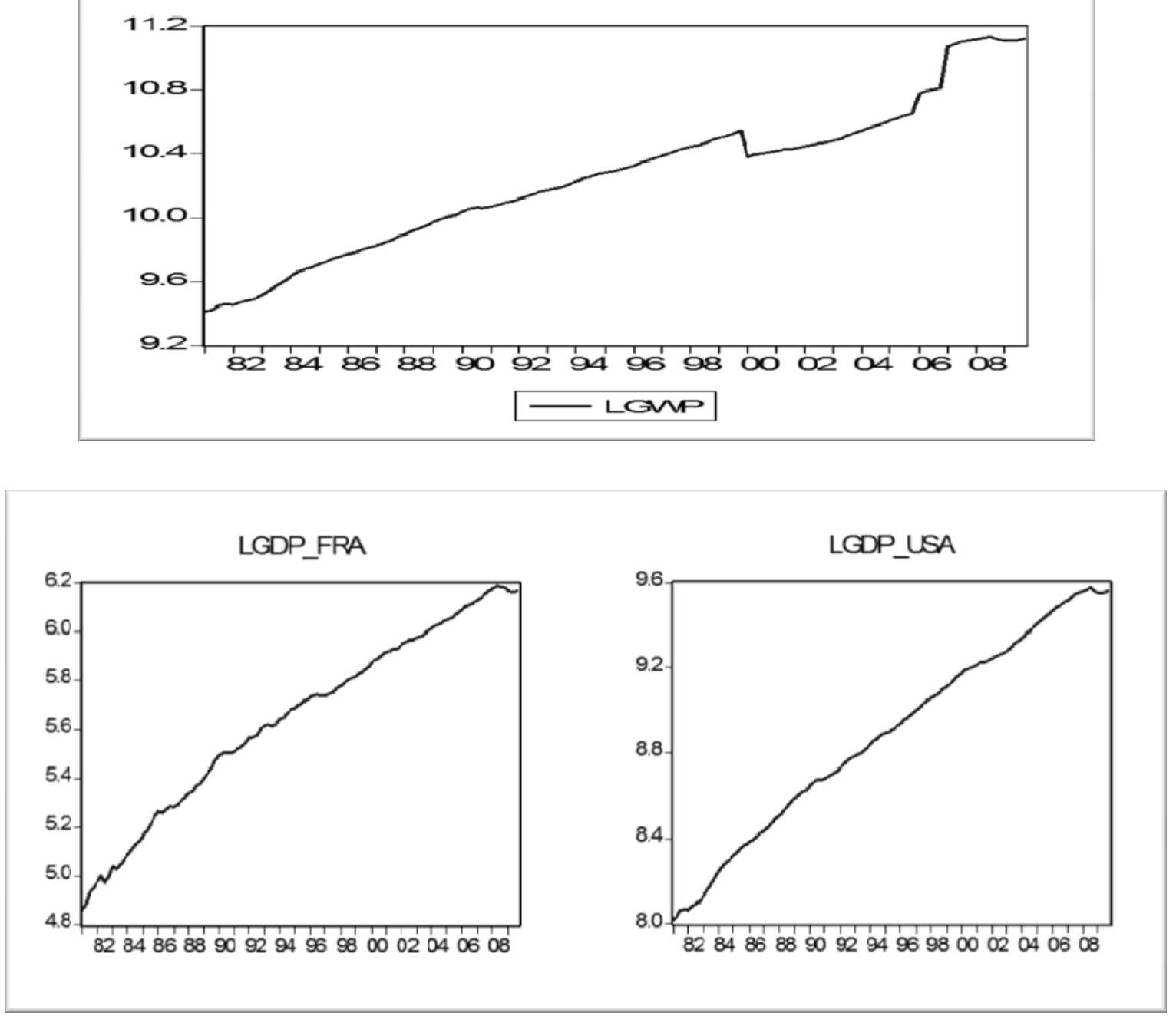

Figure 8. Foreign income, quarterly basis (1981Q1 -2009Q4)

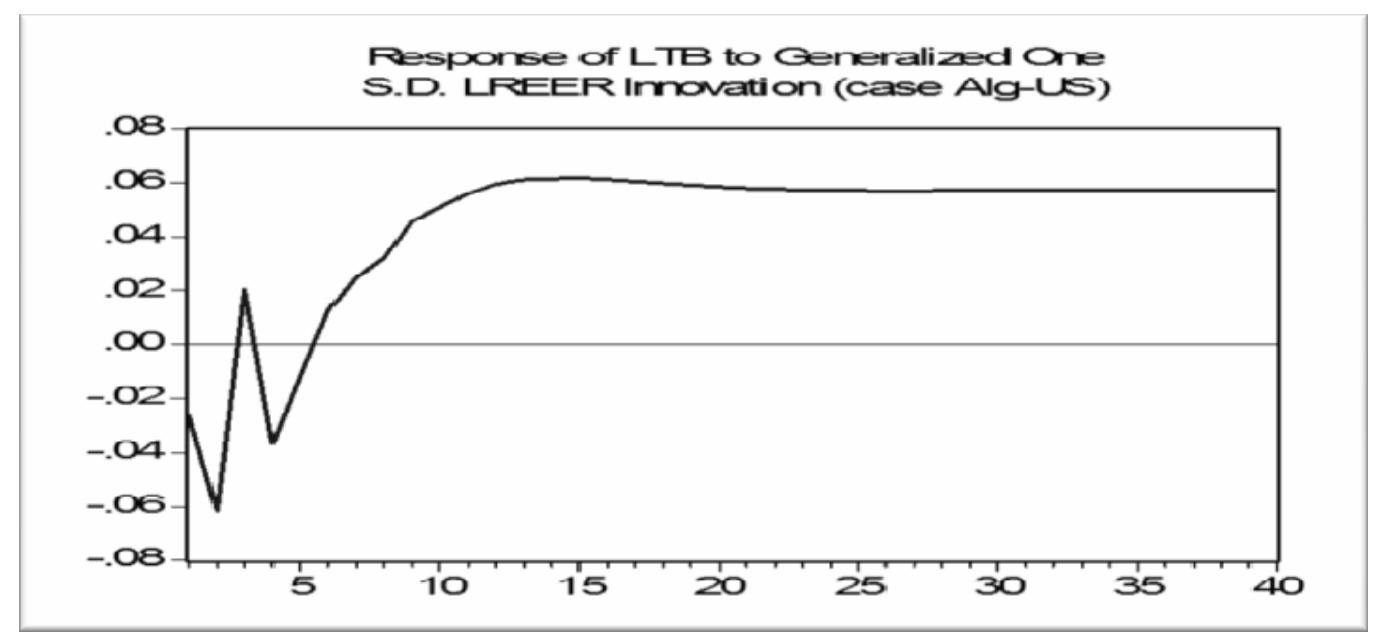

Figure I. The response of Algeria trade ratio to one standard deviation shock of REER 
Response of LTB to Generalized one S.D. Innovations of LREER(case Ag-Fra)

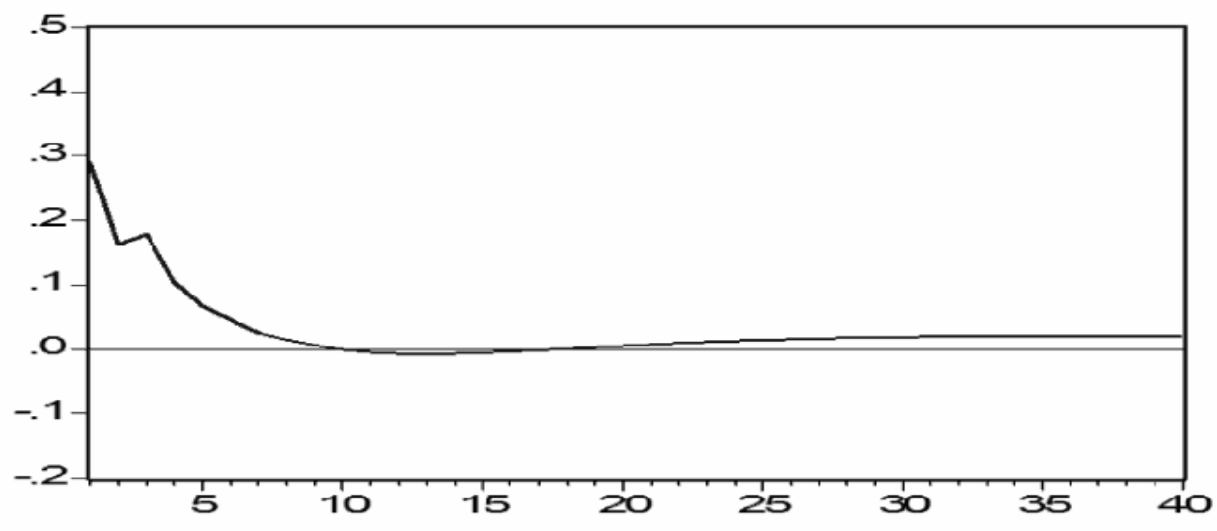

Figure II. The response of Algeria trade ratio to one standard deviation shock of REER

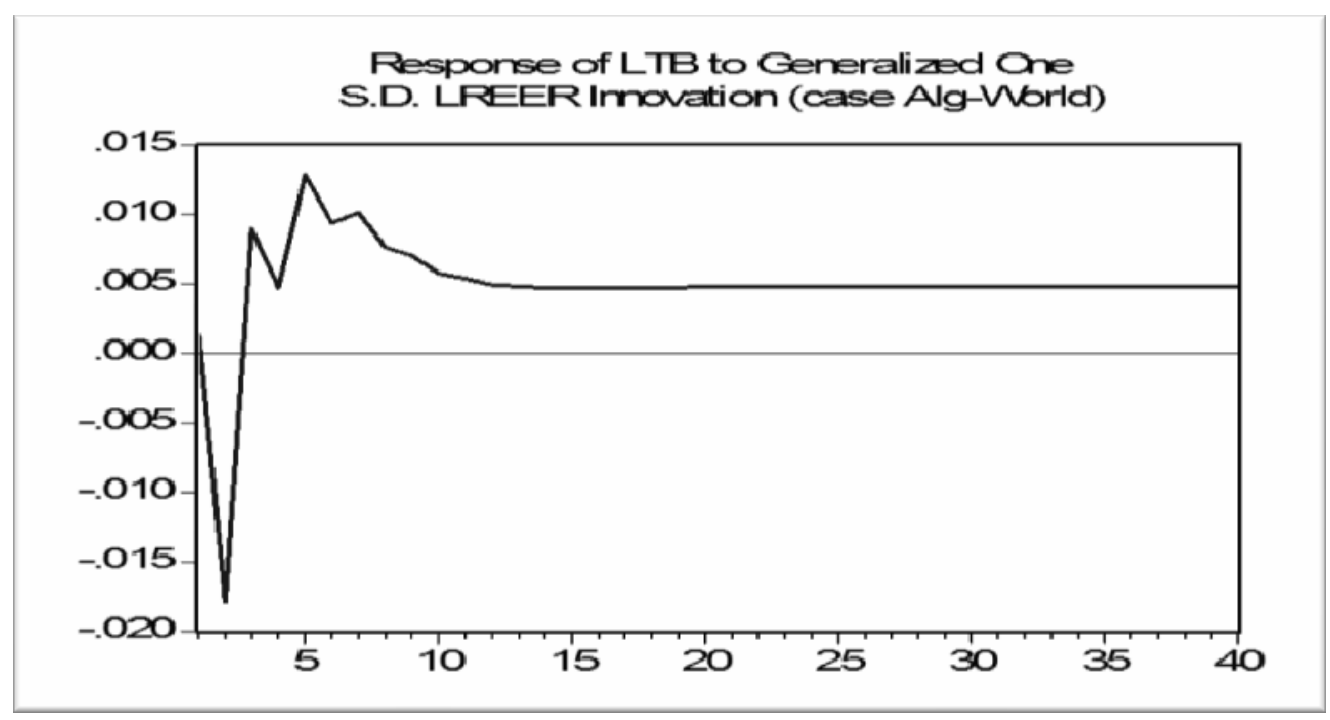

Figure III. The response of Algeria trade ratio to one standard deviation shock of REER 